\title{
СТРОГИЙ СТИЛЬ ВИЛЕНСКОГО КЛАССИЦИЗМА
}

\author{
Валерий Морозов \\ Кафедра теории и истории архитектуры, Белорусский национальный технический университет, \\ Проспект Независимости, 65, 220013 Минск, Беларусь \\ Кафедра градостроительства, Белостокский технический университет, \\ ул. Грюнвальдская, 11/15, 15-893 Белосток, Польша \\ Эл.nочта:wmorozow@tut.by
}

Поступила 18 января 2010 г.

Резюме. Строгий стиль виленского классицизма представляет собой крупное явление в архитектуре Восточной Европы наряду с барочным классицизмом, ампиром и рациональным направлением. В статье определен круг построек, имена создателей, характерные черты, особенности и значение виленского классицизма. Значительно расширены сведения о творчестве выдающегося литовского архитектора Л. Стуоки-Гуцявичюса. Доказано, что в 1780-е годы по его проектам было осуществлено строительство дворца католического архиепископа и перестройка костела кармелитов в Могилеве. Показан характер распространения строгого стиля виленского классицизма в архитектуре белорусских и литовских земель. Строгий стиль сознательно выбирало для своих построек патриотически настроенное местное дворянство, демонстрировавшее в повседневной жизни спартанское «рыцарское» поведение. Благодаря этому был создан облик «храмовидного» усадебного дома с простым объемным построением и величественным классицистическим портиком на главном фасаде.

Ключевые слова: виленский классицизм, строгий стиль, Л. Стуока-Гуцявичюс, романтизм, масонство.

\section{Введение}

В истории архитектуры и искусства Великого княжества Литовского существуют художественные явления, которые относятся к высшим проявлениям художественной культуры населявших эту страну народов, с наибольшей полнотой отражают их достижения и характеризуют самоидентичность. Среди них одним из главных является виленский классицизм.

В настоящей статье предпринята попытка определить круг построек строгого виленского классицизма, имена их создателей - заказчиков и архитекторов, показать его характерные черты и особенности, определить смысл и значение, которые несло в себе это художественное явление.

\section{1. История изучения виленского классицизма}

Начало изучению виленского классицизма было положено выдающимся польским исследователем В. Татаркевичем (Tatarkiewicz 1966). Он впер- вые выделил виленский классицизм как особое явление в архитектуре, охарактеризовал его в сопоставлении с варшавским классицизмом, определил его главные постройки в Вильно - кафедральный собор и ратушу, отметил строгий характер его форм, показал, что его главным создателем был архитектор Л. Стуока-Гуцявичюс и что значительное влияние на создание виленского классицизма оказала французская авангардная архитектура конца XVIII в.

Исследования В. Татаркевича продолжил Э. Будрейка, который подготовил и издал монографию об архитекторе Л. Стуоке-Гуцявичюсе, в которой несколько расширил круг построек зодчего (Budreika 1954). Кроме того, Э. Будрейка указал на влияние творчества Стуоки-Гуцявичюса на его учеников и коллег по Виленскому университету М. Шульца и К. Подчашинского и охарактеризовал некоторые их постройки (Будрейка 1965). 
В. Левандаускас, начиная с 1990-х гг., сосредоточил свое внимание на изучении творчества К. Подчашинского, который, несмотря на свою связь с Виленским университетом, в значительной степени являлся интерпретатором уже иного явления в классицистической стилистике - рационального направления, которое отличалось от строгого стиля виленского классицизма и несло в себе иной смысл (Levandauskas 1994).

Благодаря изданию в 1994 г. второго тома истории архитектуры Литвы был собран наиболее полный материал об архитекторах, работавших в регионе в конце XVIII - начале XIX в., представлена информация о наиболее значительных произведениях архитектуры, на основании изучения литературных и архивных источников уточнены датировка и авторство многих построек (Lietuvos ... 1994).

На рубеже XX и XXI вв. существенный вклад в понимание виленского классицизма как целостного художественного явления внес труд «В круге виленского классицизма» (W kręgy wileńskiego klasycyzmu ... 2000), в котором представлена широкая панорама развития классицизма в живописи, скульптуре, архитектуре и прикладном искусстве Вильно.

Исследования архитектуры классицизма на белорусских землях, проведенные автором настоящей статьи, показали, что строгий стиль виленского классицизма вышел далеко за пределы столицы и получил распространение в застройке городов Великого княжества Литовского и особенно в дворцово-усадебном строительстве (Морозов 2007). Это позволяет представить строгий стиль виленского классицизма как крупное явление в архитектуре классицизма Восточной Европы наряду с барочным классицизмом, ампиром, рациональным направлением, как оригинальное национальное явление, сформировавшееся под влиянием местных условий.

\section{2. Л. Стуока-Гуцявичюс - создатель строгого стиля виленского классицизма}

Постройки виленского классицизма создавались многими зодчими, работавшими в регионе в конце XVIII - начале XIX вв. и в различной степени связанными с художественной культурой Вильно. Однако главную роль играл выдающийся литовский архитектор Л. Стуока-Гуцявичюс, создавший главные классицистические постройки в Вильно, ставший первым заведующим кафедрой архитектуры Главной литовской школы. Его деятельность пришлась на сложный, трагический период в жизни государства (разделы Речи Посполитой и утрата народом собственной государственности) и охватывала эпоху романтизма. Поэтому для того, чтобы не только очертить круг построек виленского классицизма, узнать их художественные особенности, но и постичь смысл и содержание стиля виленского классицизма, необходимо прежде всего обратиться к личности главного создателя стиля виленского классицизма - архитектора Л. Стуоки-Гуцявичюса, так как известно, что личность художника эпохи романтизма, его жизнь были подчас эмоциональнее и содержательнее его искусства, а в чертах биографии мастера скрывалось то, что было запечатлено в его работах (Турчин 1981: 104-105).

Прежде всего Л. Стуока-Гуцявичюс был известным местным архитектором, что было довольно редко в ту уже достаточно отдаленную от нас эпоху, когда его окружали в основном архитекторы иностранного происхождения - Дж. Сакко, К. Спампани, М. Кнакфус и другие. Л. СтуокаГуцявичюс родился в Миганицах в Вилкомирском повете в крестьянской семье. Учился в пиарской школе в Паневежисе, затем в семинарии и иезуитской академии в Вильно.

Определяющей чертой характера Л. СтуокиГуцявичюса было то, что он был патриотом своей родины. Он являлся одним из главных соратников полковника Ясинского в подготовке восстания в Великом княжестве Литовском в 1793 г., участвовал в битве под Солами, а в битве под Вороновом 25 июля 1794 г. был ранен (Gucewicz Wawrzyniec 1960-1961: 134). За участие в восстании подвергся репрессиям и был временно отстранен от руководства кафедрой. Желание Л. Стуоки-Гуцявичюса изменить жизнь к лучшему на основе идей французской буржуазной революции и вылилось в создание простой, без украшений архитектуры, которая несла в себе эти идеи.

Конечно же, он знал местную архитектуру, деревянное зодчество и в своем творчестве обдуманно использовал ее традиции. Кроме того, будучи заведующим кафедрой архитектуры в Главной литовской школе, он фактически руководил подготовкой архитекторов в Великом княжестве Литовском и, значит, был обязан развивать традиции архитектуры своего народа.

Существенным моментом творческой биографии архитектора было также то, что после получения образования у себя на родине он стажировался за границей - в Италии и Франции. В Италии он ознакомился с античной архитектурой, столь популярной в эпоху Просвещения, а во Франции - с последними достижениями французских зодчих 
эпохи революции - Ж. Суффло и К. Леду. Влияние французской архитектуры сказалось в том, что в его творчестве, в отличие от большинства его коллег, проявились черты, свойственные французской авангардной архитектуре.

На творчество Стуоки-Гуцявичюса оказал влияние и тот факт, что он был масоном. В 1778 г. он был принят в масонскую ложу, а в 1788 г. вступил в масонскую ложу «Gorliwy Litwin» в Вильно (Gucewicz Wawrzyniec 1960-1961: 134). Как известно, масоны не доверяли изложение своих идей текстам, а использовали язык символов. Для этого наилучшим образом подходили занятия архитектурой, которая считалась масонами очень привлекательной и находилась на высокой ступени масонской лестницы, отображающей степень совершенствования человека (Масонство ... 1991: 106). Через творения архитектуры масоны стремились воздействовать на современное им общество, улучшить его. Поэтому произведения архитекторов-масонов отличались символичностью, стремлением использовать в композиции зданий чистые геометрические формы. Это подтверждается текстами писем Л. Стуоки-Гуцявичюса к другу, в которых зодчий говорит о своем стремлении через архитектуру показать людям правду (Tatarkiewicz 1966: 107).

Существенным для понимания творчества Л. Стуоки-Гуцявичюса является и то, что он был педагогом, воспитателем. Как руководитель подготовки архитекторов в Главной литовской школе он должен был быть не только практиком, но и теоретиком архитектуры. Известно, что он являлся автором трактата по архитектуре на итальянском языке, а также учебных программ. Поэтому с уверенностью можно предполагать, что идеи его архитектурного творчества получили распространение среди его учеников.

\section{3. Творчество Л. Стуоки-Гуцявичюса}

В каких же постройках проявились характерные черты строгого виленского классицизма? Прежде всего рассмотрим работы создателя этого стиля Л. Стуоки-Гуцявичюса.

Наиболее значительными и широко известными его постройками являются здания ратуши и кафедрального собора в Вильно (рис. 1,2). Они характеризуются обилием колоннад, сдержанным использованием декоративных средств, общим объемным построением зданий в виде простых геометрических фигур.

Известной работой Л. Стуоки-Гуцявичюса, оказавшей значительно меньшее влияние на архитек-

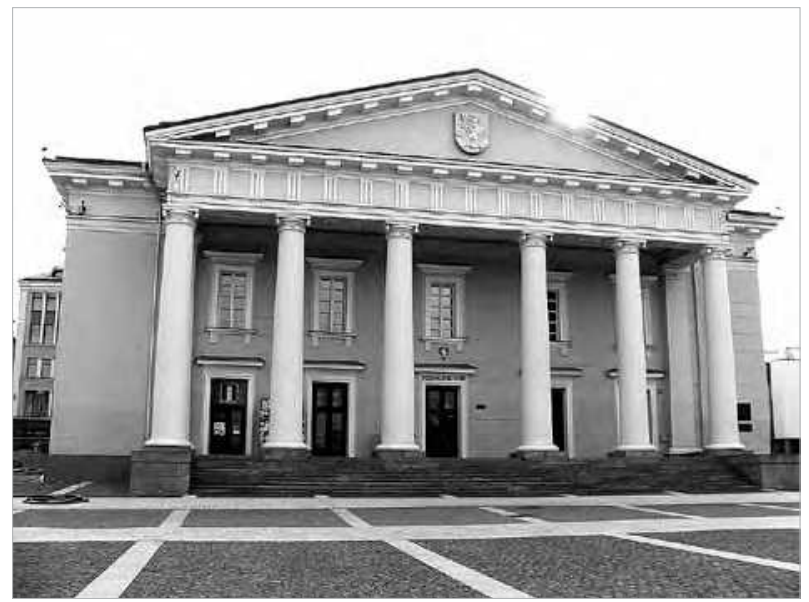

Рис. 1. Вильно. Ратуша, арх. Л. Стуока-Гуцявичюс, 1785-1799 гг. Фасад, фото автора

Fig. 1. Vilnius. City Hall, arch. L. Stuoka-Gucevičius, 1785-1799. Facade, photo by V. Morozov

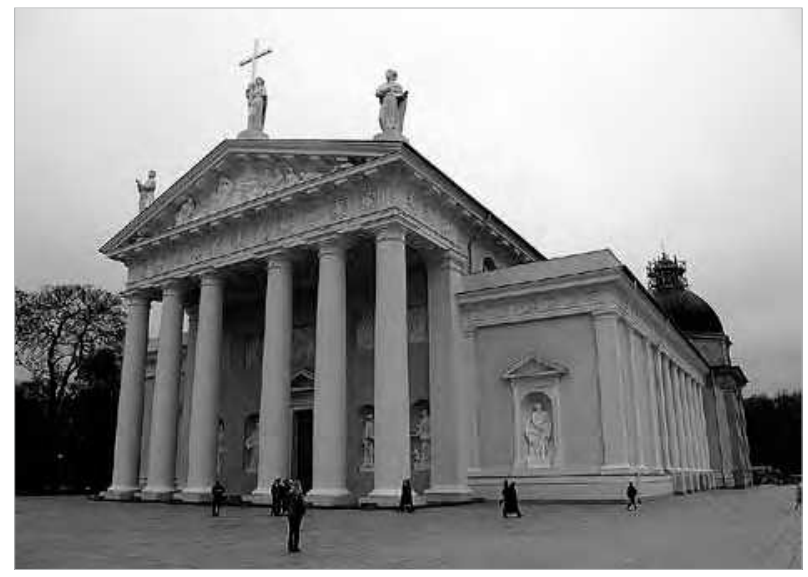

Рис. 2. Вильно. Кафедральный костел св. Станислава, арх. Л. Стуока-Гуцявичюс, 1799-1801 гг. Фасад, фото автора

Fig. 2. Vilnius. Main Roman St. Stanislav's Church, arch. L. Stuoka-Gucevičius, 1799-1801. Facade, photo by V. Morozov

туру Великого княжества Литовского, нежели его виленские постройки, являлся дворцово-парковый ансамбль в Веркяй, созданный после получения поместья в 1779 г. в собственность И. Массальским. Л. Стуока-Гуцявичюс был привлечен владельцем к обустройству новой резиденции лишь с 1781 г. Поэтому главный корпус и два флигеля являются в определенной мере совместной работой Л. СтуокиГуцявичюса и М. Кнакфуса, который в течение первых полутора лет начинал возведение комплекса, а более поздние постройки являются произведениями Л. Стуоки-Гуцявичюса. К ним относятся малый дворец - кубовидная, двухэтажная, завершающа- 
яся куполом постройка, квадратное в плане трехэтажное здание виллы, конюшни с центральным корпусом, увенчанным башней и украшенным со стороны главного фасада шестиколонным портиком дорического ордера, а также здание мельницы, напоминавшее по внешнему облику античный греческий храм.

С большой степенью вероятности к творчеству Л. Стуоки-Гуцявичюса исследователи относят костел в Судерве, возведенный в 1802-1822 гг., уже после смерти архитектора (Budreika 1991). Строгие формы здания соответствуют творческому почерку Л. Стуоки-Гуцявичюса, а использование в культовой постройке облика ротонды широко применялось в масонских картинах в качестве символического изображения храма счастья, что было, безусловно, известно зодчему, являвшемуся масоном.

Л. Стуока-Гуцявичюс строил многие усадебные дома, однако точных сведений об этом мало и не все атрибуции исследователей его творчества со временем находят подтверждение. Так, относимый Э. Будрейкой в творчеству зодчего дворец в Деречине в действительности был построен по велению А. Сапеги в качестве учебного здания - Академии находящимся на службе у Сапег архитектором И. Беккером (Морозов 2007: 296-298). Наиболее же вероятно, что к творчеству зодчего относятся усадебные дома И. Пилсудского в Чабышках и М. Костровицкого в Орлянах (ок. 1800 г.) (Aftanazy 1993: 70, 290). Их объединяет использование прямоугольного плана и наличие в средней части здания классического портика, зачастую отмечавшего двухэтажную повышенную часть здания, а также удачные пропорции как всей постройки, так и отдельных ее частей.

Многолетние исследования архитектуры классицизма позволили расширить сведения о творчестве Л. Стуоки-Гуцявичюса на белорусских землях. Это касается его работ для архиепископа Ст. Богуш-Сестрженцевича, являвшегося любимцем И. Массальского - главного мецената Л. Стуоки-Гуцявичюса - и в 1784 г. назначенного главой римско-католической церкви в Российской империи, в результате чего затеявшего обширное строительство.

В этой связи необходимо напомнить об известном факте из творческой биографии Л. СтуокиГуцявичюса - строительстве по его проекту костела в Молятичах Могилевской губернии - вотчине Ст. Богуш-Сестрженцевича. Основанием для его подтверждения являлась издавна известная исследователям гравюра, выполненная Л. СтуокойГуцявичюсом и представлявшая собой несколько измененную копию гравюры Д. Б. Пиранези, изображающей собор св. Петра в Риме и опубликованной в 1756 г. в четырехтомном издании «Римские древности». Надпись на гравюре гласит: «Костел св. Станислава в Молятичах в Мстиславском (уезде - В. М.) на Бело-Руси» (рис. 3) (Библиотека ... ).

Костел в Молятичах был построен в 1787-1794 гг. и представлял собой уменьшенную копию собора св. Петра в Риме (Центральный ... ф. 822). В 1835 г. здание было передано православной церкви, а в 1943 г. разрушено. Впечатление о внешнем облике костела можно составить по фотографии начала ХХ в. (рис. 4) (Научная ... ). Использование облика собора св. Петра при возведении костела в Молятичах было предопределено теоретическими установками классицизма, основной принцип которого гласил, что совершенства в искусстве можно достичь лишь путем подражания великим произведениям древности. Кроме того, выбор в качестве аналога для костела в белорусской вотчине Ст. Богуш-Сестрженцевича главного собора католического мира является свидетельством обращения зодчего к «говорящей» архитектуре, что свидетельствует о связи зодчего с новейшей архитектурой Франции.

Подтвержденный документально факт выполнения Л. Стуокой-Гуцявичюсом проекта для Ст. Богуш-Сестрженцевича позволяет более пристально обратиться к изучению иных построек, создававшихся под патронатом архиепископа, и

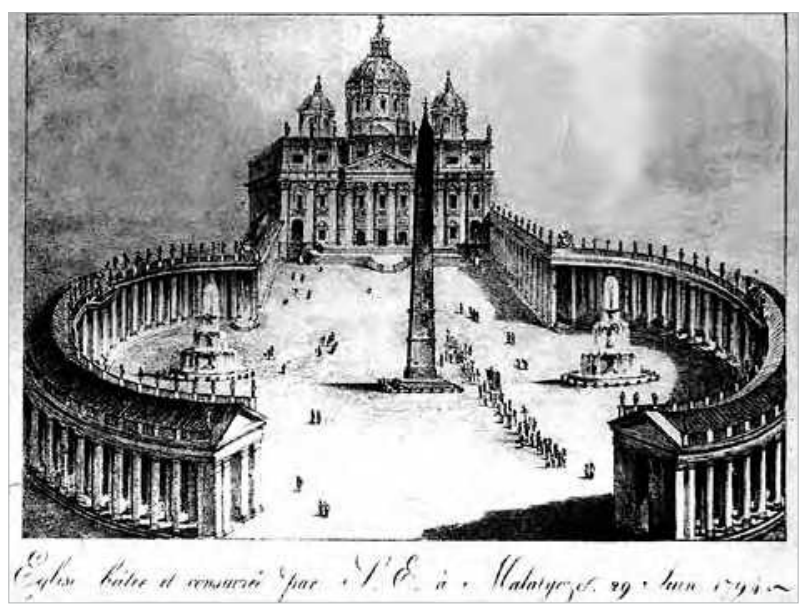

Рис. 3. Молятичи. Костел св. Станислава, арх. Л. СтуокаГуцявичюс, 1787-1794 гг. Гравюра из собрания Отдела рукописей Библиотеки Академии наук Литвы в Вильнюсе

Fig. 3. Moliatichi. Roman St. Stanislav's Church, arch. L. Stuoka-Gucevičius, 1787-1794. Engraving from the collection of Manuscript Department, Library of the Lithuanian Academy of Sciences, Vilnius 


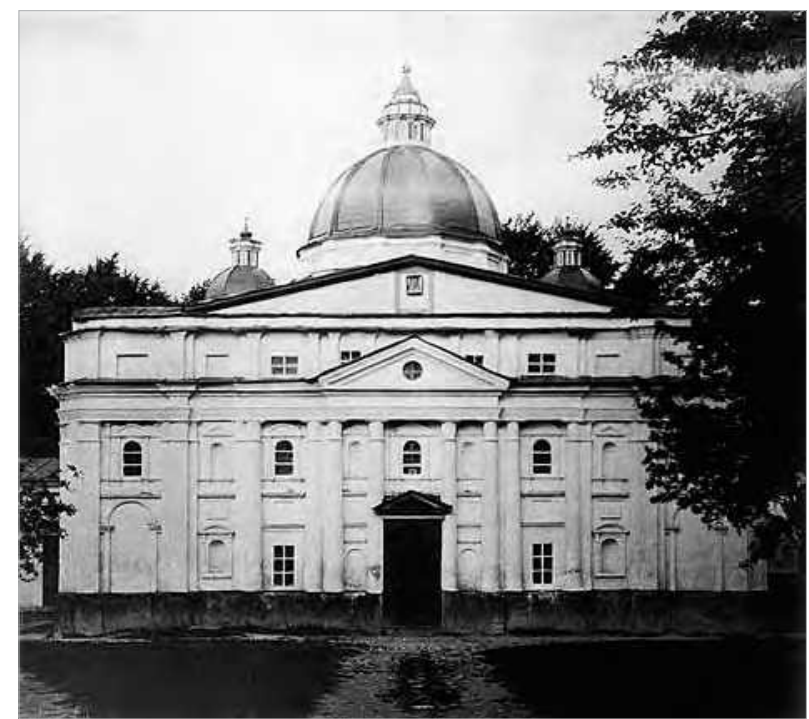

Рис. 4. Молятичи. Костел св. Станислава, арх. Л. СтуокаГуцявичюс, 1787-1794 гг. Фасад, фото из собрания Отдела рукописей Библиотеки Виленского университета

Fig. 4. Moliatichi. Roman St. Stanislav's Church, arch. L. Stuoka-Gucevičius, 1787-1794. Facade, photo from the collection of Manuscript Department, Library of Vilnius University

рассмотреть их под углом причастности к творчеству известного зодчего.

После первого раздела Речи Посполитой в 1772 г. в состав Российской империи вошло многочисленное население католического вероисповедания. В связи с этим встал вопрос об устройстве руководящего органа и поиске кандидатуры на пост главы католической церкви на присоединенных землях. Выбор Екатерины II пал на талантливого человека епископа Ст. Богуш-Сестрженцевича, проживавшего в Обольцах вблизи Могилева. 17 января 1782 г. было утверждено Могилевское архиепископство, а 29 января 1784 г. Ст. БогушСестрженцевич стал именоваться митрополитом всех римско-католических церквей в Российской империи (Живописная ... 1994).

В связи с этим в 1780-е годы в Могилеве под руководством нового архиепископа развернулось обширное строительство. Выполненный в стиле барокко фасад костела кармелитов был перестроен в стиле классицизма, а по соседству с ним был возведен дворец архиепископа. Постройки формировали одну из сторон создававшейся в городе площади и составляли единый комплекс (рис. 5).

Тот факт, что постройки возводились одновременно, у них был единый заказчик, они располагались по соседству друг с другом и были выполне- ны в одном стиле, свидетельствует о том, что они были созданы одним архитектором. Идентичность в подходах к реконструкции костела в Могилеве и кафедрального костела в Вильно, в типологии построек для руководства католической церковью в Могилеве и Вильно, факт создания Л. СтуокойГуцявичюсом проекта костела в Молятичах для Ст. Богуш-Сестрженцевича, который, как и постройки в Могилеве и Вильно, был возведен в 1780-е годы, а также множество исторических фактов, подтверждающих контакты Ст. БогушСестрженцевича с И. Массальским и СтуокойГуцявичюсом, свидетельствуют о том, что именно Стуокой-Гуцявичюсом были выполнены проекты для Могилева - перестройки костела кармелитов и резиденции Ст. Богуш-Сестрженцевича.

Костел кармелитов в Могилеве был перестроен в 1788-1794 гг. и освящен в честь св. Станислава, что, кстати, было выполнено по аналогии с виленским кафедральным собором. Изменения коснулись лишь главного фасада (рис. 6, 7). Был разобран барочный щипец, фасад закрыт четырехколонным портиком, по бокам которого были возведены две трехъярусные башни. Изменился рисунок оконных проемов, пилястр и карнизов. Здание приобрело вид античного храма, в котором доминировал портик с треугольным фронтоном. Вместе с тем в очертаниях фасада угадывался облик собора св. Петра в Риме. Идентичной была общая схема фасадов зданий с портиком посередине, фланкированным двумя невысокими башнями, горизонтальная развернутость фасадов, выделение тяжелого, прорезанного окнами аттика, рисунок окон с лучковыми и треугольными фронтонами, а также пропорции и характер декора башен.

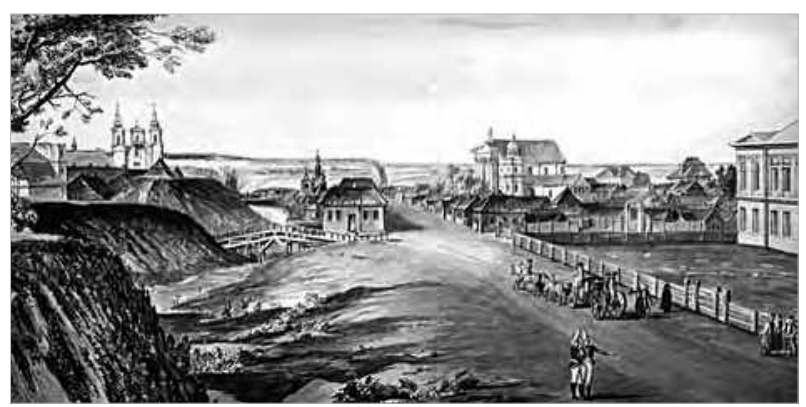

Рис. 5. Могилев. Вид дворца католического архиепископа и костела св. Станислава, начало XIX в. Рисунок из собрания Отдела рукописей Библиотеки Академии наук Украины во Львове

Fig. 5. Mogiliev. View of the catholic bishop's palace and Roman St. Stanislav's Church, beginning of the 19th c. Drawing from the collection of Manuscript Department, Library of the Ukrainian Academy of Sciences, Livov 


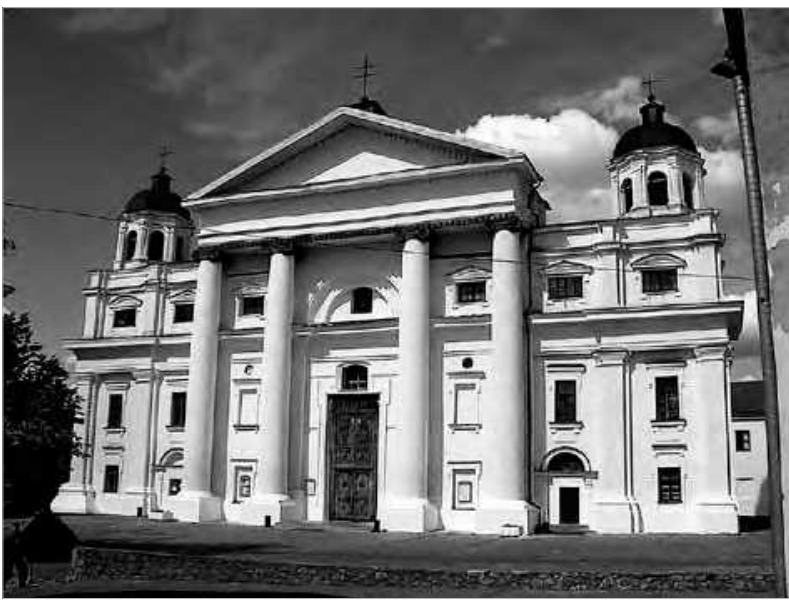

Рис. 6. Могилев. Костел св. Станислава, арх. Л. СтуокаГуцявичюс, 1788-1794 гг. Фасад, фото автора

Fig. 6. Mogiliev. Roman St. Stanislav's Church, arch. L. Stuoka-Gucevičius, 1788-1794. Facade, photo by V. Morozov

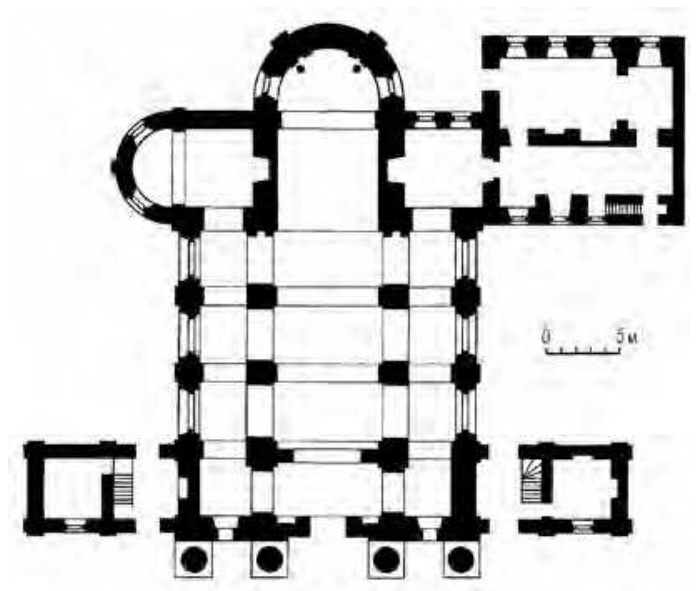

Рис. 7. Могилев. Костел св. Станислава, арх. Л. СтуокаГуцявичюс, 1788-1794 гг. План, рисунок автора

Fig. 7. Mogiliev. Roman St. Stanislav's Church, arch. L. Stuoka-Gucevičius, 1788-1794. Plan, drawing by V. Morozov

При возведении в 1787 г. дворца католического архиепископа не были использованы столь радикальные решения, как при перестройке костела, и в постройке не проявились черты строгого классицизма. Замысел здания известен благодаря сохранившимся чертежам, которые являются, по всей вероятности, копией проекта Л. СтуокиГуцявичюса (рис. 8, 9) (Центральный ... ф. 1488). Дворец представлял собой традиционную палладианскую композицию с двухэтажными главным зданием и флигелями, соединенными закругленными колоннадами. В постройке были использо- ваны сдвоенные колонны, придававшие зданию «римский» дух и связывавшие его с архитектурой собора св. Петра в Риме. Ощутима близость к работам Л. Стуоки-Гуцявичюса, что проявилось в утяжеленных пропорциях колоннад, использовании парапетов на крыше, рисунке обрамлений окон.

\section{4. Работы зодчих виленской архитектурной школы}

Строгий стиль виленского классицизма получил развитие в творчестве архитекторов виленской школы, учеников Л. Стуоки-Гуцявичюса и его последователей. Значительное распространение он получил в архитектуре общественных зданий, что соответствовало светской направленности

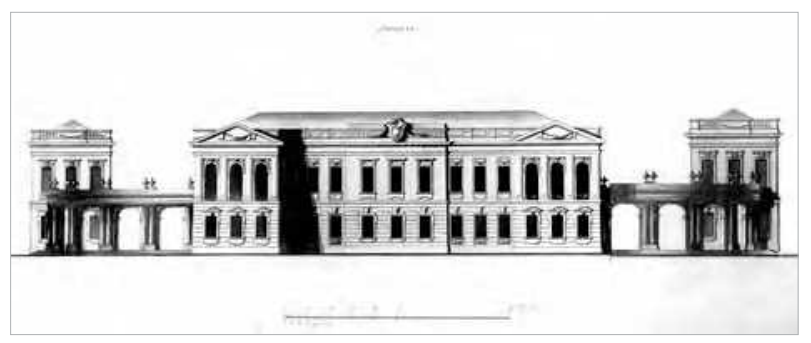

Рис. 8. Могилев. Дворец католического архиепископа, арх. Л. Стуока-Гуцявичюс, 1787 г. Фасад, Центральный государственный исторический архив России в СанктПетербурге

Fig. 8. Mogiliev. Catholic bishop's palace, arch. L. StuokaGucevičius, 1787. Facade, Central State Historical Archive, Russia, St. Petersburg

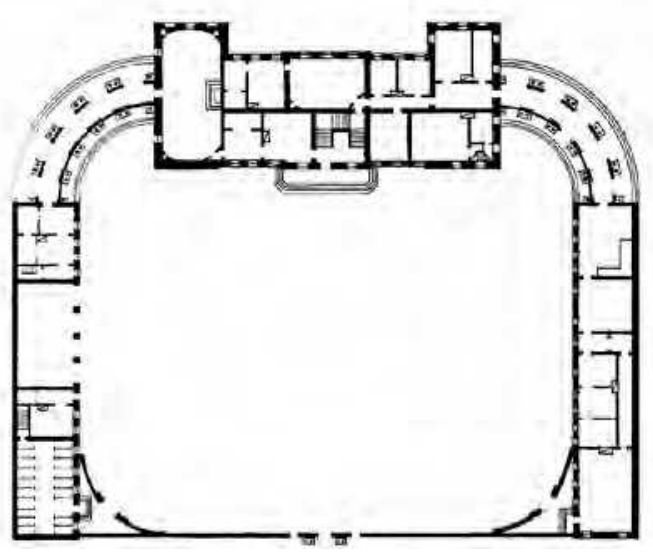

Рис. 9. Могилев. Дворец католического архиепископа, арх. Л. Стуока-Гуцявичюс, 1787 г. План, Центральный государственный исторический архив России в СанктПетербурге

Fig. 9. Mogiliev. Catholic bishop's palace, arch. L. StuokaGucevičius, 1787. Plan, Central State Historical Archive, Russia, St. Petersburg 
архитектуры того времени. Прежде всего обратимся к архитектуре учебных зданий, так как их строительство в связи с организацией Виленского учебного округа в 1803-1832 гг. направлялось из Вильно и здесь в условиях значительной централизации архитектурно-строительного дела в Российской империи проявились местные черты и особенности.

Строгий стиль виленского классицизма наиболее ярко проявился в облике здания гимназии в Свислочях Гродненской губернии, построенной в 1824 г. по проекту К. Подчашинского, являвшегося архитектором Виленского учебного округа (рис. 10, 11) (Morozow 1990: 270, 271). Общая композиция зданий была близка образцовому проекту гимназии для городов Полтавской и Черниговской

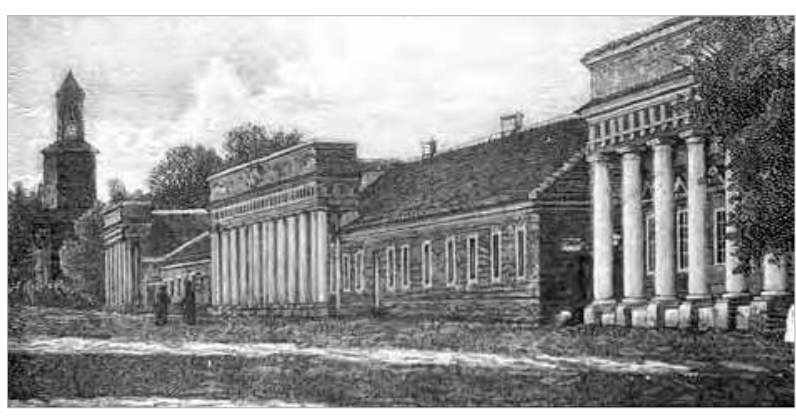

Рис. 10. Свислочь. Гимназия, арх. К. Подчашинский, 1824 г. Фрагмент фасада, гравюра конца XIX в. (по Kłosy, 19 marca 1887 , s. 205)

Fig. 10. Svisloch. Gymnasium, arch. K. Podchashinski, 1824. Fragment of the facade, engraving, end of the 19th c. (by Kłosy, 19 March 1887, p. 205)

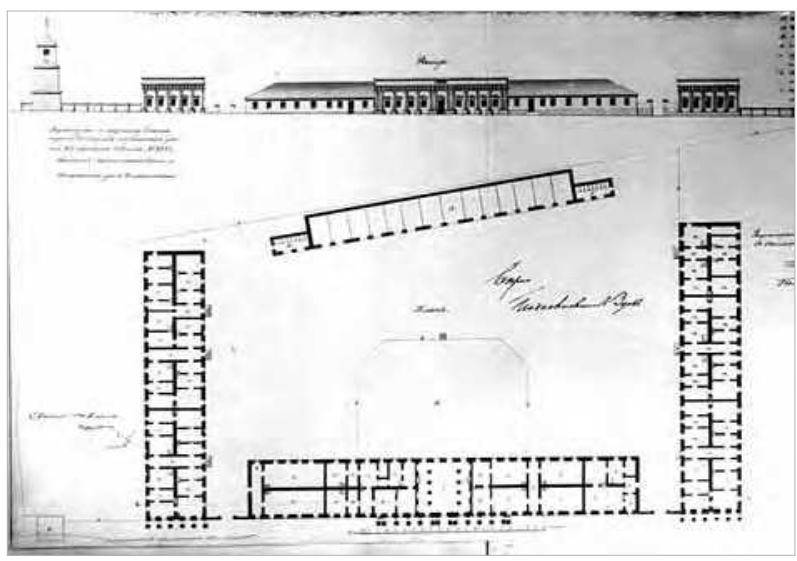

Рис. 11. Свислочь. Гимназия, арх. К. Подчашинский, 1824 г. План и фасад, Центральный государственный исторический архив России в Санкт-Петербурге

Fig. 11. Svisloch. Gymnasium, arch. K. Podchashinski, 1824. Plan and facade, Central State Historical Archive, Russia, St. Petersburg губерний, выполненному петербургским архитектором Л. Руской в 1804 г., однако облик зданий гимназии отличался строгостью, простотой в отборе выразительных средств. Обширные колоннады на главном фасаде придавали зданию облик античной греческой школы, а тяжеловатые пропорции колоннад, к тому же выполненных из камня, когда все здания строились из дерева, были характерны для местной архитектурной практики XVIIXVIII вв. Следует отметить, что для Свислочей в начале XIX в. проекты гимназии и костела, напоминавшего древнегреческое святилище, создавал ученик и соратник Л. Стуоки-Гуцявичюса М.Шульц (рис. 12, 13) (Morozow 1990:268-270, 273). Впоследствии именно свислочская гимназия стала одним из центров развития вольнолюбивых идей в

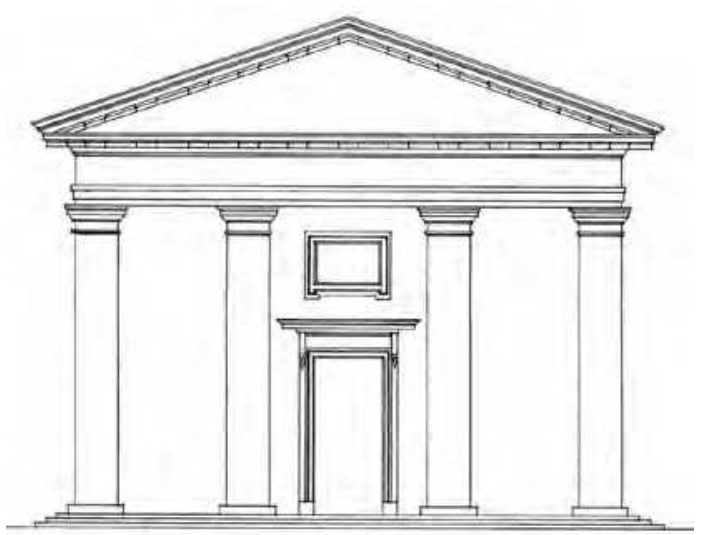

Рис. 12. Свислочь. Костел, арх. М. Шульц, 1802-1803 гг. Проект фасада, Отдел рукописей Библиотеки Виленского университета

Fig. 12. Svisloch. Roman Church, arch. M. Shulc, 1802-1803. Design of the facade, the collection of Manuscript Department, Library of Vilnius University

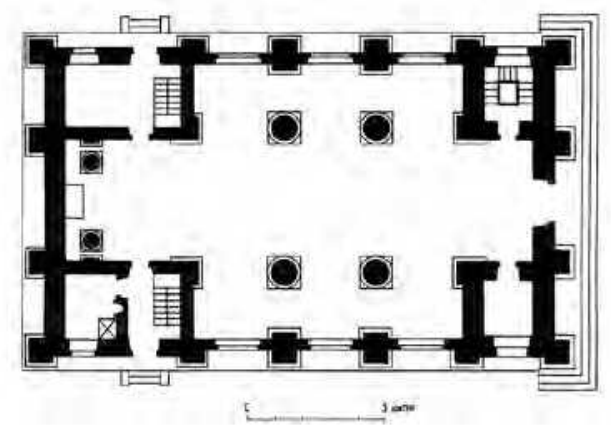

Рис. 13. Свислочь. Костел, арх. М. Шульц, 1802-1803 гг. Проект плана, Отдел рукописей Библиотеки Виленского университета

Fig. 13. Svisloch. Roman Church, arch. M. Shulc, 18021803. Design of the plan, the collection of Manuscript Department, Library of Vilnius University 
Великом княжестве Литовском, чему в определенной степени способствовала героическая античная архитектура зданий.

Влияние виленских построек Л. Стуоки-Гуцявичюса проявилось в архитектуре ратуши в Гродно, строительство которой было завершено в 1807 г. (рис. 14). Благодаря этому в архитектурный облик центра второго по значению города Великого княжества Литовского были включены крупные античные портики, которые из-за их расположения стали, как и в Вильно, главными акцентами центрального пространства города.

Строгий стиль виленского классицизма получил распространение в архитектуре главных площадей белорусских местечек и малых городов, территориально тяготевших к Вильно и не затронутых регулярной перепланировкой, проводившейся русскими специалистами. Благодаря строительству торговых рядов, включавших колоннады, античная архитектура активно входила в их облик. Эти постройки - торговые ряды в Новогрудке

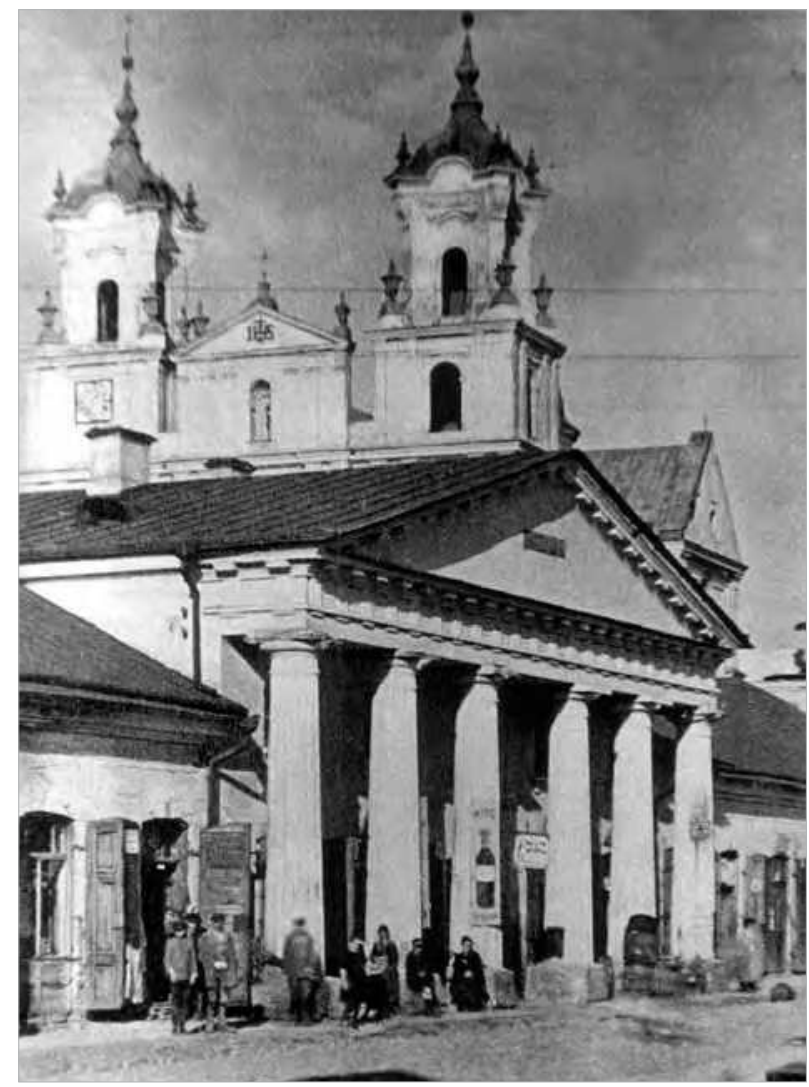

Рис. 14. Гродно. Ратуша, 1807 г. Фото Я. Булгака из собрания Отдела рукописей Библиотеки Академии наук Литвы в Вильнюсе

Fig. 14. Grodno. City Hall, 1807. Photo by J. Bulgak from the collection of Manuscript Department, Library of the Lithuanian Academy of Sciences, Vilnius
(1835-1836 гг., арх. В. Михаэлис) и Годучишках Виленской губернии (1828 г.) - возводились местными архитекторами (рис. 15, 16) (Квитницкая 1983: 46, 47).

Наиболее значительно строгий стиль виленского классицизма проявился в усадебном строительстве. На усадебное строительство не распространялось влияние централизованного проектирования по проектам из Петербурга, а владельцы усадеб - местная шляхта приглашали виленских архитекторов.

Наиболее значительным примером распространения строгого виленского классицизма явилась усадьба в Залесье Виленской губернии, в

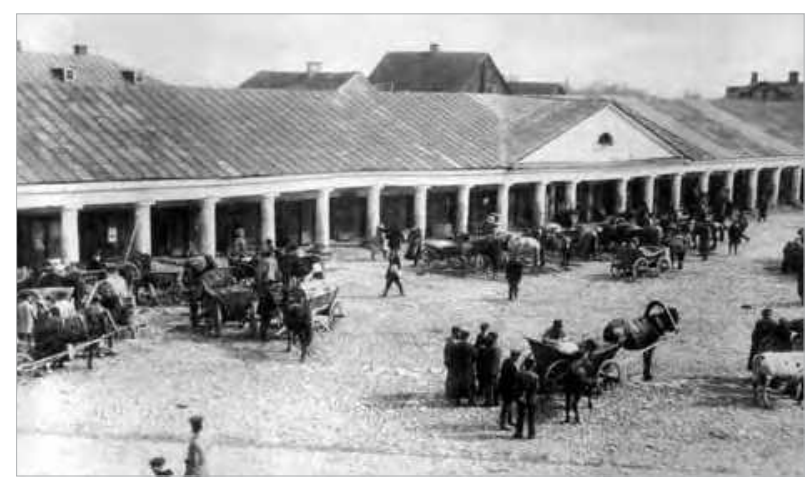

Рис. 15. Новогрудок. Торговые ряды, 1835-1836 гг., арх. В. Михаэлис. Фрагмент фасада, фото Я. Булгака из собрания Отдела рукописей Библиотеки Академии наук Литвы в Вильнюсе

Fig. 15. Novogrudok. Commercial building, 1835-1836, arch. V. Mihaelis. Fragment of the facade. Photo by J. Bulgak from the collection of Manuscript Department, Library of the Lithuanian Academy of Sciences, Vilnius

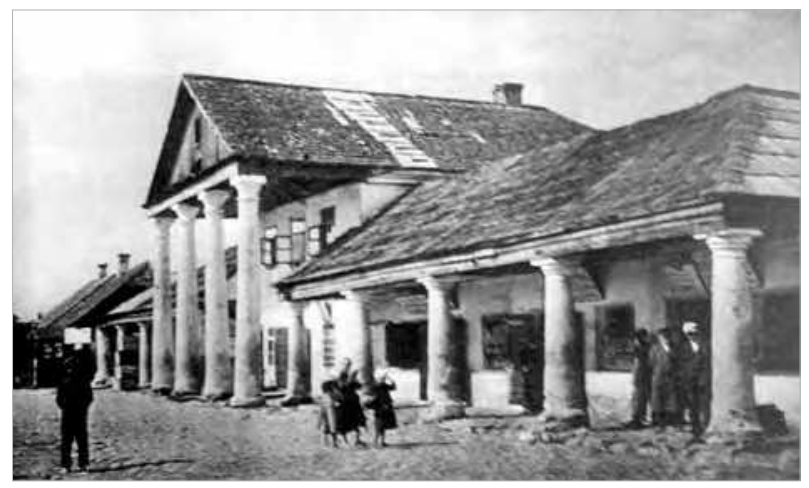

Рис. 16. Годучишки. Торговые ряды, 1828 г. Фрагмент фасада, фото Я. Булгака из собрания Отдела рукописей Библиотеки Академии наук Литвы в Вильнюсе

Fig. 16. Goduchishki. Commercial building, 1828. Fragment of the facade. Photo by J. Bulgak from the collection of Manuscript Department, Library of the Lithuanian Academy of Sciences, Vilnius 
1802-1822 гг. принадлежавшая выдающемуся общественному деятелю М. К. Огинскому (рис. 17). Здесь по проекту М. Шульца был возведен классицистический дворец и устроен пейзажный парк (Morozow 1990: 268, 270, 271). В архитектуре дворца использованы чистые геометрические объемы и высокий канонический портик, придававший главному корпусу вид храма. В парке были устроены павильоны в виде греческих святилищ, находились памятные знаки в честь побывавших здесь героев освободительного движения (рис. 18).

Другим крупным дворцово-усадебным комплексом, возведенным в начале XIX в. архитектором виленской школы А. Коссаковским, являлся дворец в Воложине (рис. 19) (Baranowski 1981: 215-220). Здания дворцового комплекса представляют собой необычную композицию. Напротив главного корпуса был возведен идентичного вида флигель, а наиболее значительной по величине постройкой являлось здание оранжереи. Дворец представлял собой характерную компоновку, когда центральная часть одноэтажного здания имела два этажа и была отмечена большим портиком. Характеризуя облик здания, современники отмечали его строгий спартанский вид и практически полное отсутствие лепных украшений (Aftanazy 1993: 435). Облик же построенного неподалеку в 1806-1815 гг. бернардинского костела напоминал виленский кафедральный собор, а характерная для виленского классицизма тема дорической колоннады была использована и в звоннице костела (рис. 20).

В начале XIX в. на территории Великого княжества Литовского были возведены многочисленные усадебные дома с чертами строгого виленского классицизма. Главным античным элементом дома являлся портик, доступный взору всех, кто находился неподалеку. Он не только свидетельствовал о принадлежности хозяина к дворянству, но и выражал стремление владельца включить в архитектуру собственного жилища своеобразную «цитату» из древнегреческой архитектуры - облик античного храма. Неподалеку зачастую располагался небольшой костел в виде древнегреческого святилища.

\section{5. Смысл и значение строгого стиля виленского классицизма}

В заключение следует определить, что же означал строгий стиль виленского классицизма, каков его смысл и каково вкладываемое в него заказчиками и архитекторами содержание. Прежде всего следует отметить, что появление строгого стиля не было уникальным явлением в европейской архитектуре конца XVIII в. Стремление к ограничению изобразительных средств проявилось

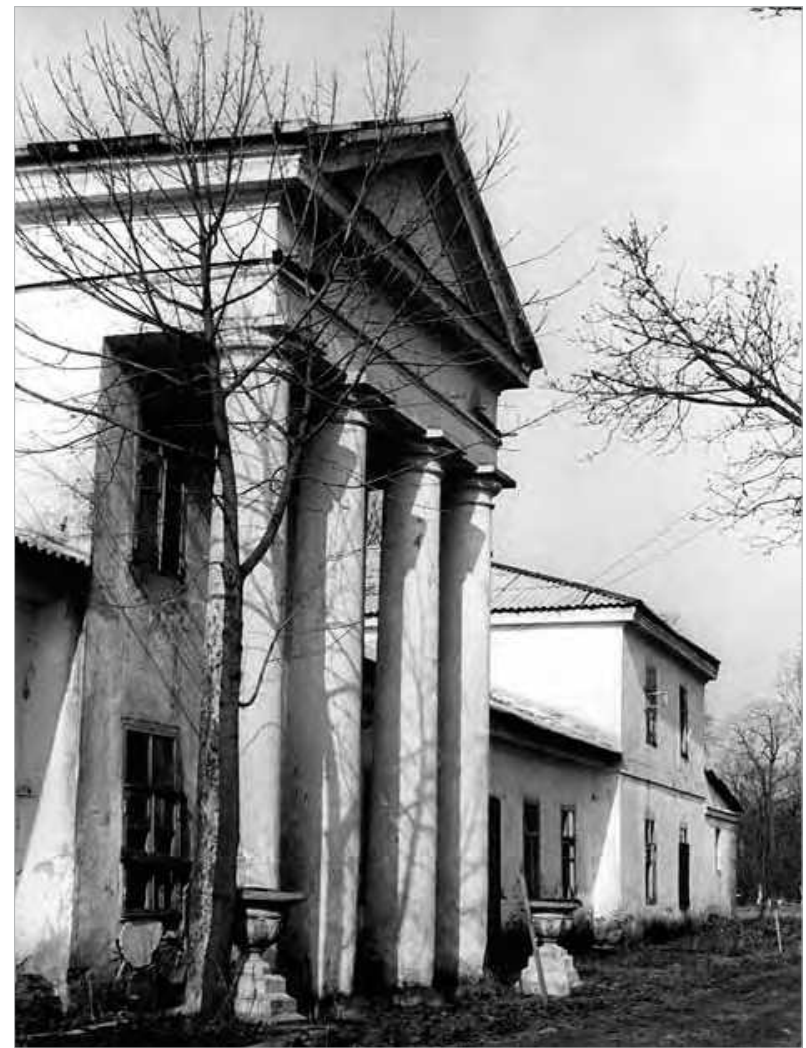

Рис. 17. Залесье. Дворец князя М. К. Огинского, арх. М. Шульц, 1802-1822 гг. Фрагмент фасада, фото автора

Fig. 17. Zalesie. Prince M. K. Oginsky's palace, arch. M. Shulc, 1802-1822. Fragment of the facade, photo by V. Morozov

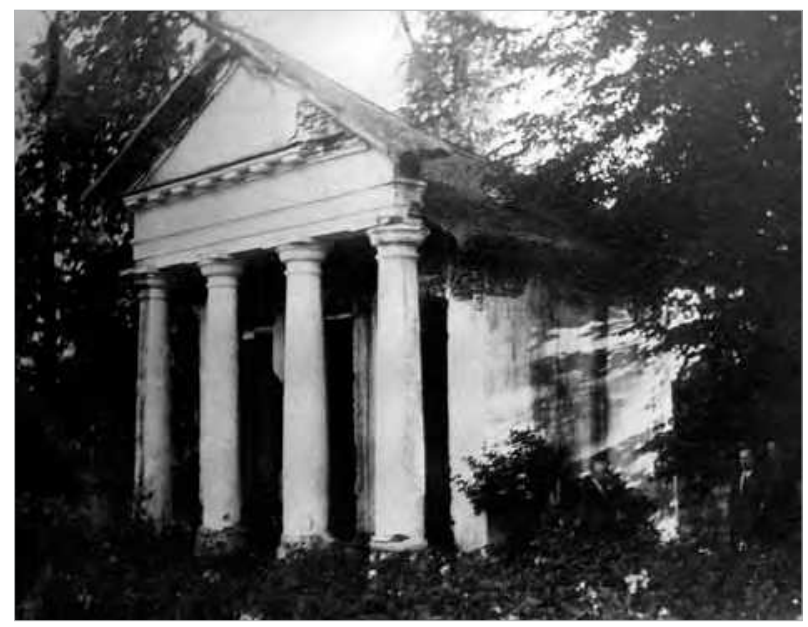

Рис. 18. Залесье. Каплица в парке дворца князя М. К. Огинского, арх. М. Шульц, 1802-1822 гг. Фрагмент фасада, фото из собрания Отдела рукописей Библиотеки Академии наук Литвы в Вильнюсе

Fig. 18. Zalesie. Chapel in Prince M. K. Oginsky's palace park, arch. M.Shulc, 1802-1822. Fragment of the facade, photo from the collection of Manuscript Department, Library of the Lithuanian Academy of Sciences, Vilnius 


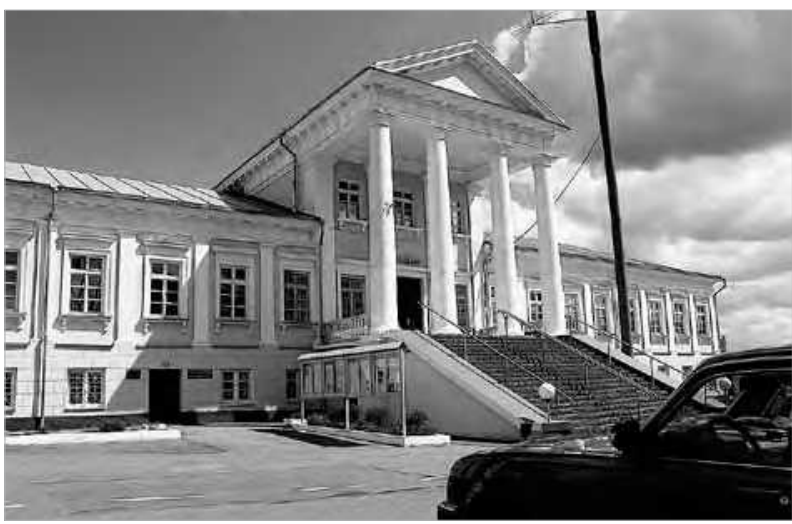

Рис. 19. Воложин. Дворец графа И. Тышкевича, арх. А. Коссаковский, начало XIX в. Фрагмент фасада, фото автора

Fig. 19. Volozin. Count I. Tyshkevich's palace, arch. A. Kossakovsky, beginning of the 19th c. Fragment of the facade, photo by V. Morozov

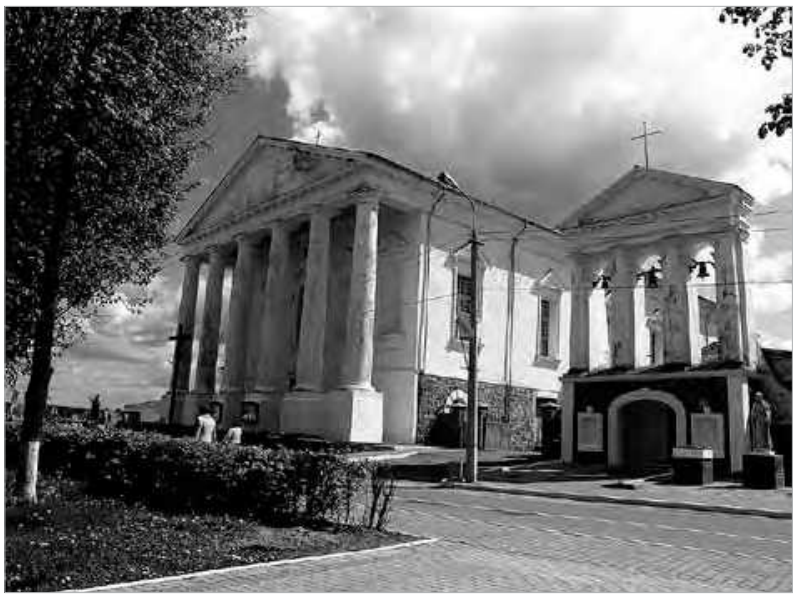

Рис. 20. Воложин. Костел бернардинцев св. Иозефа, арх. А. Коссаковский, 1806-1815 гг. Фрагмент фасада, фото автора

Fig. 20. Volozin. Bernardin Roman St. Jozef's Church, 1806-1815. Fragment of the facade, photo by V. Morozov

в архитектуре стран Восточной Европы, в частности, Российской империи, с 1780-х гг. и связано со стремлением к созданию подлинно античной архитектуры, с приглашением итальянских зодчих и развивалось в русле палладианства. Постройки же виленского классицизма отличались большей строгостью форм, их излишней лапидарностью и огрубленностью, аскетизмом в выборе архитектурных средств. Следует помнить, что строгий стиль виленского классицизма получил развитие в 1780-1820-х гг. во время наибольшего развития романтизма. Характерной чертой романтизма в двух главных сферах человеческих проявлений искусстве и обыденной жизни - является решающее влияние искусства на бытовое поведение (Лотман 1994: 180-183).

В романтическую эпоху главные заказчики монументального строительства - дворяне строили свою жизнь по законам искусства, а учитывая значительные потрясения в их судьбах, судьбах их родины - разделы Речи Посполитой, подавление национально-освободительных движений, - по законам трагедии. Они выбирали строгий, спартанский образ жизни и стремились окружить себя строгой спартанской архитектурой. Строгий стиль выбирали патриоты, которые демонстрировали в повседневной жизни своеобразное «рыцарское» поведение. Их дома, крупные шляхетские старосветские постройки выделялись отсутствием лепных украшений и простотой убранства, подчас нарочито театрально выставляемой. Этим они были близки постройкам французских архитекторовавангардистов времен французской буржуазной революции, несли в себе революционный заряд. Строгий стиль виленского классицизма создал облик «храмовидного» усадебного дома шляхты Великого княжества Литовского с простым объемным построением и строгим классическим портиком на фасаде. Именно такие постройки стали традиционными для сельского пейзажа Великого княжества Литовского рубежа XVIII-XIX вв. Подобное здание было описано А. Мицкевичем в поэме «Пан Тадеуш» и напоминало дом в Чомброве под Новогрудком (рис. 21). Именно в таких домах не только происходили романтические свидания, но и вызревали великие освободительные идеи, которые привели к восстаниям 1794, 1831 и 1861 гг.

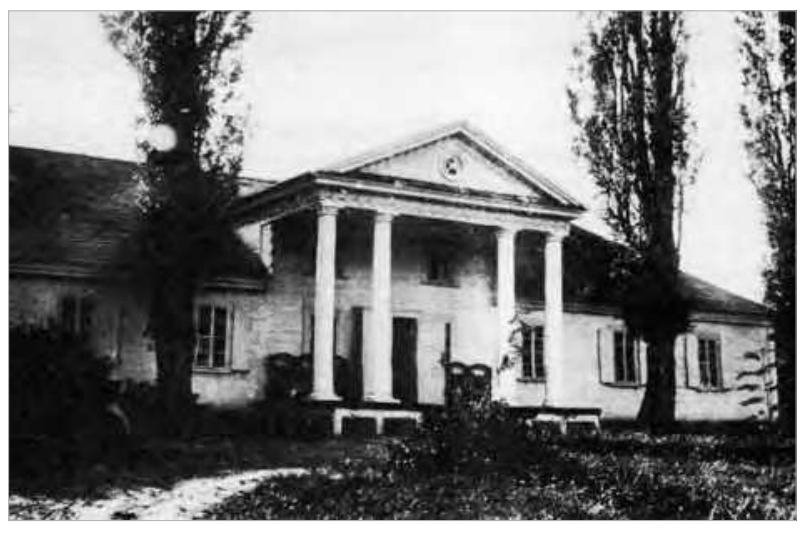

Рис. 21. Чомбров. Усадебный дом Карповича, начало XIX в. Фрагмент фасада, фото по Р. Афтаназию

Fig. 21. Chomborov. Karpovich's country house, beginning of the 19th c. Fragment of the facade, photo by R. Aftanaz 
Поэтому строгий стиль виленского классицизма можно назвать стилем сопротивления. Он получил развитие в архитектуре Великого княжества Литовского вплоть до середины XIX в., а затем уступил место рациональному направлению, которое несло в себе уже иные идеи - идеи экономии и бережливости.

\section{Литература}

Библиотека Академии наук Литвы. Отдел рукописей. № 4509.

Будрейка, Э. С. 1965. Расивет в архитектуре классицизма Литвы (Творчество Лауринаса Стуоки-Гуиевичуса). Рукопись докторской диссертации в национальной библиотеке России в Москве.

Живописная Россия, Литовское и Белорусское Полесье. 1994. Репринтное воспроизведение изд. 1882 г. Минск: Беларуская Энцыклапедыя.

Квитницкая, Е. Д. 1983. Центры городов Белоруссии в XVI - первой половине XIX в., Архитектурное наследство, Вып. 31, 46, 47.

Лотман, Ю. М. 1994. Беседы о русской культуре. Быт и традииии русского дворянства (XVIII - начало XIX века). Санкт-Петербург: Искусство - СПБ.

Масонство в его прошлом и настоящем. 1991. Репринтное воспроизведение издания 1915 года, т. 2, Москва: СП "Икпа".

Морозов, В. Ф. 2001. Классииизм в архитектуре Беларуси. Рукопись докторской диссертации в Белорусском национальном техническом университете. Минск.

Морозов, В. Ф. 2007. Гражданская и монументальная архитектура Беларуси. Классицизм, в кн: Архітэктура Беларусі: нарысы эвалющы ва уссходнеславянскім і еурапейскім кантэксие, т. 3. Мінск: Беларуская навука, 296-298.

Научная библиотека Виленского университета, Отдел рукописей, ф. 82, № 382.

Турчин, В. 1981. Эпоха романтизма в России. К истории русского искусства первой трети ХІХ столетия. Москва: Искусство.

Центральный государственный исторический архив России в Санкт-Петербурге, ф. 822, оп. 12, ед. хр. 2630.

Центральный государственный исторический архив России в Санкт-Петербурге, ф. 1488, оп. 2, ед. хр. 699, л. $1,2$.

Aftanazy, R. 1993. Dzieje rezydencji na dawnych kresach Rzeczypospolitej, Część 1. Wielkie Księstwo Litewskie, t. 4, Województwo wileńskie. Wrocław-Warszawa-Kraków: Ossolineum.

Baranowski, A. 1979, 1981. Lietuvos TSR architektūros klausimai , VI (II), Wilno (1979). Biuletyn historii sztuki (1981) 2: $215-220$

Budreika, E. 1954. Architektas Laurynas Stuoka-Gucevičius. Vilnius: Valstybiné politinès ir mokslinès literatūros leidykla. 166 p.
Budreika, E. 1991. Działalność architektoniczna Wawrzyńca Gucewicza. Wybrane zagadnieni, w ks.: Lituano-Slavica Posnaniensia, Studia historiae artium, t. V: 180-186.

Gucewicz Wawrzyniec. 1960-1961, w ks.: Polski słownik biograficzny, t. IX. Wrocław-Warszawa-Kraków-Gdańsk.

Levandauskas, V. 1994. Architektas Karolis Podčašinskis. Vilnius: Vilniaus dailès akademijos leidykla. $160 \mathrm{p}$.

Lietuvos architektūros istorija. Nuo XVII a. pradžios iki XIX a. vidurio. T. II. 1994. Vilnius: Mokslo ir enciklopediju leidykla. $592 \mathrm{p}$.

Morozow, W. 1990. Działalność architektów warszawskich i wileńskich na Białorusi w końcu XVIII i 1 połowie XX wieku, Biuletyn Historii Sztuki, t. 52.

Tatarkiewicz, W. 1966. Dwa klasycyzmy: wileński i warszawski, w ks.: O sztuce Polskiej XVII i XVIII wieku. Architektura, rzeźba, Warszawa: Państwowe wydawnictwo naukowe, 89-107.

W kręgy wileńskiego klasycyzmu. Katalog wystawy przygotowany pod kierunkiem Elżbiety Charazińskiej i Ryszarda Bobrowa. Warszawa: Muzeum Narodowe w Warszawieб 2000.573 p.

\section{GRIEŽTAS VILNIAUS KLASICIZMO STILIUS}

\section{Morozov}

Santrauka. Griežtas Vilniaus klasicizmo stilius - tai žymus Rytų Europos architektūros reiškinys šalia barokinio klasicizmo, ampiro ir racionalumo krypties. Straipsnyje minimi Vilniaus klasicizmo stiliaus architektai, apibūdinti šio stiliaus pastatai, pateikti jo svarbiausi bruožai ir reikšmè. Praplèstos žinios apie žymaus lietuvių architekto L. Stuokos-Gucevičiaus kūrybą. Irodyta, kad pagal jo projektus nuo $1780 \mathrm{~m}$. buvo pastatyti arkivyskupo rūmai ir perstatyta karmelitų bažnyčia Mogiliove. Apibūdinta Vilniaus griežtojo klasicizmo stiliaus įtaka Baltarusijos ir Lietuvos žemių architektūrai. Ši stilių savo pastatams sąmoningai rinkdavo vietiniai bajorai patriotai. Buvo sukurtas sodybos rūmų, primenančių šventovę, vaizdas.

Reikšminiai žodžiai: Vilniaus klasicizmas, griežtas stilius, L. Stuoka-Gucevičius, romantizmas, masonai.

\section{“STRONG” STYLE OF VILNIUS CLASSICISM}

\section{Morozov}

Abstract. "Strong" style of Vilnius classicism was a great phenomenon in the East European architecture and existed side by side with the baroque classicism or empire style or "rational" style.

The paper determines the range of buildings, names of creators, characteristic features, peculiarities and significance of Vilnius classicism. It provides a deeper knowledge of the works of the famous Lithuanian architect V. Stuoka-Gucevičius. It is proved that in 1780 the project of the catholic Bishop's Palace and reconstruction of the Carmelite's Church in Mogiliev have been carried out by this architect. 
Spreading of Vilnius classicism "strong" style in the Belarussian and Lithuanian architecture was determined. The patriotic domestic nobility chose this style consciously because of their demonstration of the "knight" behavior in everyday life. Thanks to this style a temple appearance of a house was created by a simple space organization and grand classic portico on the main facade.

Keywords: Vilnius classicism, "strong" style, L. StuokaGucevičius, romantizm, freemasonry.

\section{VALERY MOROZOV}

Head of the Department of Theory \& History of Architecture, Belarussian National Technical University,

pr. Nezavisimosty 65, 220013 Minsk, Belarus

Professor of the Department of Urbanism \& City Planning, Belostok Technical University,

ul. Grunvaldska 11/15, 15-893 Belostok, Poland

Field of scientific interest - architecture of East European countries with the focus on the 18th and 19th c. 